\title{
Experimental investigation on ferritic stainless steel composite slabs
}

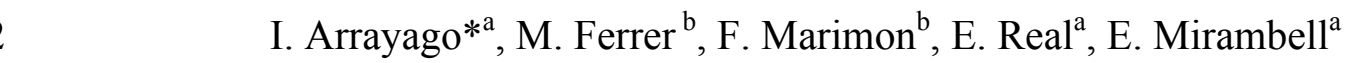

a) Department of Civil and Environmental Engineering, Universitat Politècnica de Catalunya, Jordi Girona 1-3, Barcelona 08034, Spain

b) Strength of Materials and Structural Engineering Department, ETSEIB, Universitat Politècnica de Catalunya, Avinguda Diagonal 647, Barcelona 08028, Spain

Corresponding author: Itsaso Arrayago, itsaso.arrayago@upc.edu, Tel: +34 934054156

\section{ABSTRACT}

Steel-concrete composite structures are well established in the construction of floors and roofing, being interesting solutions as steel decks act as formwork for relatively large spans and support the weight of the concrete and construction loads. However, the use of stainless steel decks in such structures has been very limited, although their mechanical properties, corrosion resistance, aesthetics and emissivity make them excellent for visually exposed composite floor slabs where the thermal capacity of the slab is mobilized as part of an energy saving strategy. This paper presents a comprehensive investigation on composite slabs with trapezoidal ferritic stainless steel decks in order to assess the performance of such structural members. Composite slabs made from EN1.4003 ferritic stainless steel and common C25/30 concrete were tested in two series of span lengths in order to determine the different parameters defining their ultimate longitudinal shear response. Reference tests on slabs with galvanized steel were also conducted with identical geometries and configurations. The $m$ and $k$ parameters used in the $m-k$ method and the design longitudinal shear strength $\tau_{\mathrm{u}, \mathrm{Rd}}$ corresponding to the Partial Connection Method have been determined according to EN 1994-1-1:2004. Finally, the behaviour of these composite slabs was compared with the performance shown by the conducted reference slabs with galvanized steel deck in terms of Ultimate and Serviceability Limit States. 


\section{KEYWORDS}

2 composite slab; ferritic stainless steel; $m-k$ method; partial connection method; tests

\section{HIGHLIGHTS}

4 - Experimental programme on composite slabs with ferritic stainless steel trapezoidal

5 deck is presented.

6 - Long span and short span slabs are tested.

7 - Parameters corresponding to $m-k$ and Partial Connection Methods are determined.

8 - Results are compared to reference tests on galvanized steel for ULS and SLS.

\section{1. INTRODUCTION}

10 The use of deck profiles as steel-concrete composite floor systems and roofing is 11 common in construction, since the steel deck acts as formwork for relatively large spans 12 and supports the weight of the concrete, as well as construction loads. Given that 13 decking profiles usually present unusual shapes and are fabricated from cold-forming 14 procedures, they are characterized by high strength-to-weight ratios, but also by a high 15 susceptibility to buckling. Trapezoidal decks have been employed in building construction since last decades, and the design of such structures is well established in EN 1994-1-1:2004 [1], although the use of stainless steel decks has been very limited

18 since it is a relatively new construction material. The low thermal expansion coefficient

19 and emissivity of ferritic stainless steels allow the mobilization of their thermal capacity

20 in visually exposed composite floor slabs as part of an energy saving strategy, reducing 21 the requirement for heat/cooling in buildings.

22 Stainless steel is a material with high initial investment requirements, although the 23 consideration of lifecycle costs demonstrate its competitiveness [2]. The absence of 24 nickel in the composition of ferritic stainless steels helps reducing and stabilizing their 25 price, making them especially attractive for construction applications, as established in 
1 [3]. As other stainless steel families, they are characterized by a nonlinear stress-strain

2 behaviour, with a combination of good mechanical and impact properties, excellent

3 corrosion resistance, better response at high temperatures and aesthetics. In recent

4 decades, the use of stainless steel for architectural and construction applications have

5 increased thanks to the research developed on the structural behaviour of stainless steel

6 members and the publication of specific design guidance. The cost of the stainless steel,

7 in relation to that of competing materials, has become much lower, while many new

8 grades and product forms are now widely available all over the world. Nowadays, the

9 stainless steel is not viewed purely as a decorative option for facades and panels and is

10 part of building structures such the roof of the Delhi Parliament Library, the UAE

11 Pavilion at the Shanghaï Expo or the roof in New Doha airport, Qatar as the largest

12 stainless steel roof in the world. There are also some examples for bridges and

13 pedestrian bridges as the Girder Bridge in Stockholm in Sweden, the Cala Galdana

14 Bridge in Menorca (Spain) and the Helix pedestrian bridge in Marina Bay, Singapore $15[4]$.

16 The research has been focussed in the last years in the cross-sectional behavior of I17 shaped, circular (CHS), rectangular (RHS) and square hollow sections (SHS) for 18 different types of stainless steels alloys such as austenitic, ferritic and duplex [5-8]. In

19 addition, studies on stainless steel members have been carried out [9-11]. Currently, a 20 new generation of research projects aimed at studying stainless steel structures and the 21 effects of the material non-linearity on the global behavior of frames is active [12-14].

22 However, the use of ferritic stainless steel decks is not generalized, so the structural 23 performance of such profiles in construction stage and as part of composite slabs needs 24 to be carefully assessed. 
1 This was addressed in the European Research Project entitled Structural Applications

2 in Ferritic Stainless Steel (SAFSS), which provided all the necessary information for the

3 assessment of ferritic stainless steel structural elements. As part of this Research

4 Project, the behaviour of trapezoidal ferritic stainless steel decks as composite floor

5 slabs was investigated (see Figure 1), as reported in Ferrer et al. [15]. First, the

6 structural performance of ferritic stainless steel decks in construction stage was

7 investigated through an extensive experimental programme, where the expressions

8 codified in EN 1993-1-3:2006 [16] and EN 1993-1-4:2006 [17] were assessed. This

9 research was reported by the authors in Arrayago et al. [18], and it was concluded that

10 in general expressions in $[16,17]$ are applicable to ferritic stainless steel decks, although

11 some modified expressions can be used if higher accuracy is required in the design.

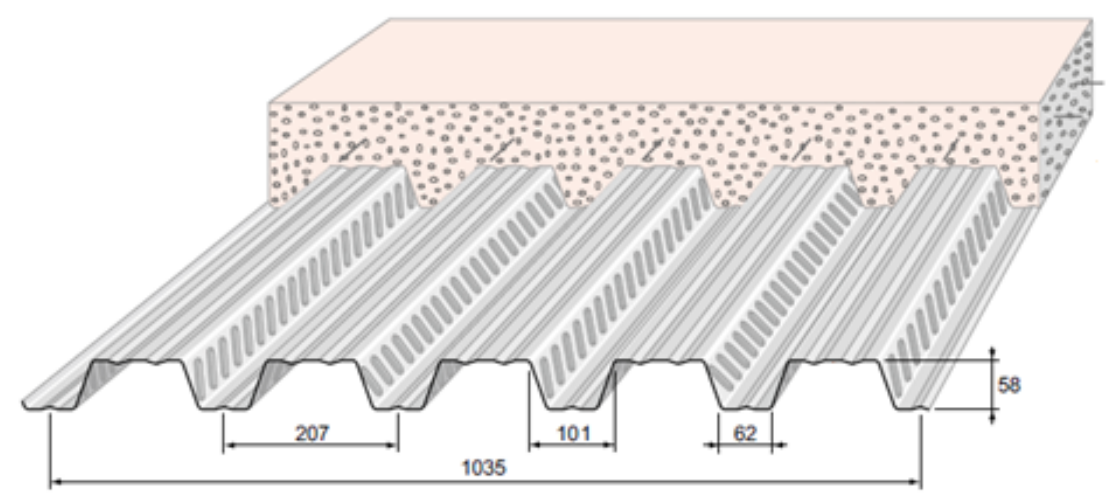

Figure 1 Trapezoidal steel deck in composite floor slab [19]

The behaviour of composite floor slab systems has been systematically investigated during the last decades through different experimental and numerical studies [20-27], and the fire performance of such structures has also been carefully characterized [2830]. In addition to the punching shear failure, the failure of composite slabs is governed by three major failure modes, as shown in Figure 2, which are bending (for considerably high shear spans $L_{s}$ ), vertical shear (for low shear spans) and longitudinal shear (for intermediate values of $L_{S}$ ), related to the relative slip between the steel deck and the concrete at supports, where the shear span $L_{s}$ is the distance from the point of 
1 application of concentrated force to its respective reaction force. This paper is focused

2 on this last failure mode, which is the most common for composite slabs, with the

3 purpose of studying the longitudinal shear performance of ferritic stainless steel decks

4 in composite slabs and to determine the values of the different parameters required for

5 the practical use of such decks.

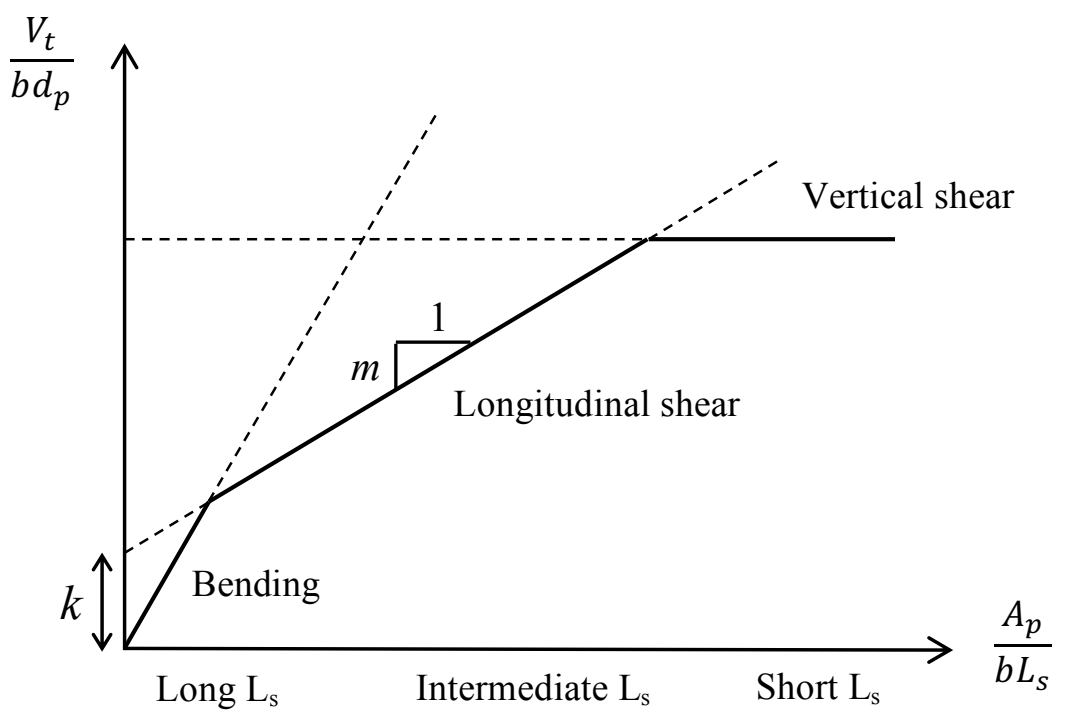

Figure 2 Failures modes for composite slabs, boundaries of the longitudinal shear failure mode

6 EN 1994-1-1:2004 [1] provides two alternative methods for the design of concrete-steel

7 composite slabs with embossments and without end anchorage: the $m-k$ method and the

8 Partial Connection Method (PCM). While the former is applicable to both ductile and

9 brittle slabs, the PCM can only be used for ductile longitudinal shear connections. The

10 longitudinal shear behaviour of composite slabs may be considered as ductile if the

11 failure load exceeds the load causing a recorded end slip of $0,1 \mathrm{~mm}$ by more than $10 \%$,

12 according to EN 1994-1-1:2004 § 9.7.3(3) [1]. Both methods require the determination

13 of different parameters which relies on full scale tests, since the complexity of the

14 failure and the parameters affecting the shear bond resistance favoured empirical design

15 methods. Consequently, the obtained parameters are limited to the variables considered

16 in the tests. In order to calculate the $m-k$ parameters, slabs with two different shear span 
1 lengths $L_{s}$ need to be tested, provided that all specimens fail showing longitudinal shear

2 failure modes. Thus, two series of three slabs with intermediate shear spans need to be

3 tested in order to determine the two empirical parameters, $m$ and $k$. Regarding the PCM,

4 the longitudinal shear strength $\tau_{u}$ (degree of interaction between the deck and the

5 concrete) can be directly derived from the ultimate bending moment resistance of four

6 slab tests showing ductile failure.

7 This paper presents the experimental programme on composite slabs with ferritic

8 stainless steel decks in order to assess the design provisions for this corrosion resisting

9 material, as well as to obtain the values of the different parameters used in the design of

10 such structures $\left(m-k\right.$ parameters and the ultimate shear stresses $\left.\tau_{u}\right)$. Provided that two

11 equivalent specimens with galvanized steel were available, additional tests were carried

12 out on these reference tests for comparison purposes. In addition, obtained results have

13 been compared with similar ferritic stainless steel-concrete composite slabs reported in

14 [31]. These alternative tests consisted on four slabs with different span lengths to those adopted in the present experimental study, which did not allowed for the estimation of the $m$ and $k$ parameters (requiring at least two series of three specimens). Moreover,

17 since the parameters derived from experimental results are limited to the variables

18 considered in the tests, specimens with additional span lengths are of interest.

\section{2. EXPERIMENTAL PROGRAMME}

20 This section describes the conducted experimental programme on composite slabs with

21 ferritic stainless steel trapezoidal decks. The geometry of the slab is first reported,

22 followed by the material properties and pouring procedure. Finally, a comprehensive 23 description of the conducted tests is provided. 


\section{$1 \quad 2.1$ DESCRIPTION OF THE SLABS}

2 The composite concrete-stainless steel slabs considered in this experimental study

3 comprised a trapezoidal ferritic stainless steel Cofraplus 60 deck and common C25/30

4 concrete.

$5 \quad$ 2.1.1 Properties of the stainless steel deck

6 The studied Cofraplus 60 profile is $0.8 \mathrm{~mm}$ thick, $58 \mathrm{~mm}$ high and presents a total width

7 of $1035 \mathrm{~mm}$, involving 5 waves, according to the requirements in EN 1994-1-1:2004 $\S$

8 B.3.3 (5) [1], which states that the total slab width needs to be wider than three times

9 the overall depth, $600 \mathrm{~mm}$ and the cover width of the profiled sheet. The upper part of

10 the waves is reinforced with two stiffeners, while the lower wave shows a single

11 stiffener. Webs are inclined with a $72^{\circ}$ angle and present several embossments to

12 guarantee a good connection between the deck and the concrete. These embossments

13 show an inclination of $60^{\circ}$ and different direction in both webs for each wave, as shown

14 in Figure 1. A detailed geometrical definition of the representative wave is shown in

$15 \quad$ Figure 3.

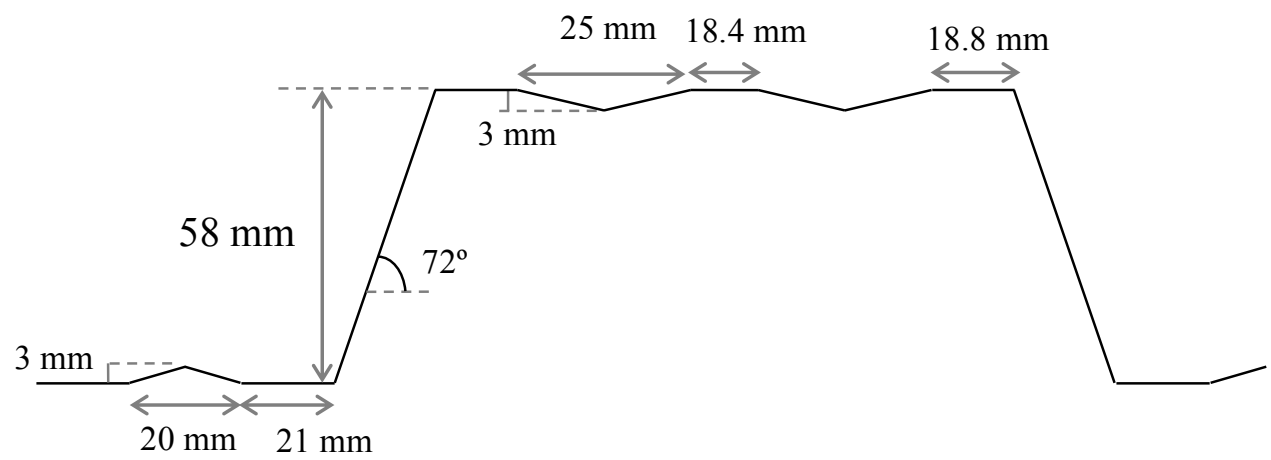

Figure 3 Detailed geometry of a representative wave of the studied deck

16 In previous investigations by Arrayago et al. [18] the strength of the ferritic stainless

17 steel trapezoidal deck under several loading conditions was investigated. The depth and

18 spacing of the embossments were found to be within the acceptance ranges defined in

19 EN 1994-1-1:2004 § B.3.3 (2) [1], which are 5\% and $10 \%$ of the nominal values, 
1 respectively. Key geometric and mechanical properties of the studied ferritic stainless

2 steel deck are presented in Figure 4 and summarized in Table 1, in which the design

3 value of the bending moment resistance of the effective cross-section of the profiled

4 steel deck $M_{p a}$ has been adopted as the experimental bending moment resistance in

5 construction stage under positive bending, according to the tests reported in [18].

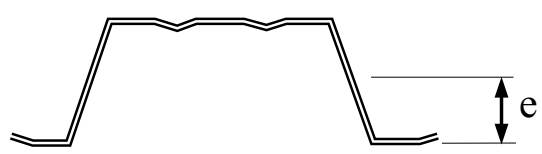

Gross-section

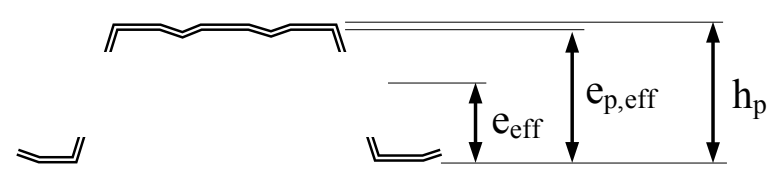

Effective cross-section

Figure 4 Definition of key geometric parameters for gross and effective cross-sections

6

7

8

Table 1 Cross-section properties of the ferritic stainless steel deck

\begin{tabular}{|c|c|c|}
\hline Parameter & Value & Description \\
\hline $\mathrm{t}$ & $0.8 \mathrm{~mm}$ & thickness of the deck \\
\hline$A_{p}$ & $1211 \mathrm{~mm}^{2}$ & cross-sectional area of the profiled steel deck \\
\hline$A_{\mathrm{pe}}$ & $910 \mathrm{~mm}^{2}$ & $\begin{array}{l}\text { effective cross-sectional area of the profiled steel deck after removing } \\
\text { the embossments }\end{array}$ \\
\hline $\mathrm{b}$ & $1035 \mathrm{~mm}$ & total width of the slab \\
\hline e & $32.1 \mathrm{~mm}$ & $\begin{array}{l}\text { the distance from the centroidal axis of the steel deck to the extreme } \\
\text { fibre of the composite slab in tension }\end{array}$ \\
\hline $\mathrm{e}_{\text {eff }}$ & $33.3 \mathrm{~mm}$ & $\begin{array}{l}\text { distance from the centroidal axis of the effective steel deck to the } \\
\text { extreme fibre of the composite slab in tension }\end{array}$ \\
\hline$e_{p, e f f}$ & $58 \mathrm{~mm}$ & $\begin{array}{l}\text { distance from the plastic neutral axis of the steel deck to the extreme } \\
\text { fibre of the composite slab in tension }\end{array}$ \\
\hline $\mathrm{M}_{\mathrm{pa}}$ & $5.7 \mathrm{kNm}$ & $\begin{array}{l}\text { design value of the bending moment resistance of the effective cross- } \\
\text { section of the profiled steel deck }\end{array}$ \\
\hline
\end{tabular}

Material properties of the ferritic stainless steel deck, obtained from tensile coupon tests conducted in [18] are summarized in Table 2, where $E$ is the Young's modulus, $\sigma_{0.2}$ is the proof stress corresponding to a $0.2 \%$ plastic strain, conventionally considered as the yield stress (equal to the yield stress $f_{y}$ for the galvanized steel), $\sigma_{u}$ and $\varepsilon_{u}$ are the ultimate strength and strain, respectively, and $n$ and $m$ are the strain hardening exponents. Similar material parameters corresponding to the coupons extracted from galvanized steel decks are also reported. 
Table 2 Key material properties of the studied decks

\begin{tabular}{ccccccc}
\hline Material & $\begin{array}{c}E \\
{[\mathrm{MPa}]}\end{array}$ & $\begin{array}{c}\sigma_{0.2} \\
{[\mathrm{MPa}]}\end{array}$ & $\begin{array}{c}\sigma_{u} \\
{[\mathrm{MPa}]}\end{array}$ & $\begin{array}{c}\varepsilon_{u} \\
{[\%]}\end{array}$ & $n$ & $m$ \\
\hline $\begin{array}{c}\text { Ferritic } \\
\text { stainless steel }\end{array}$ & 218100 & 326 & 488 & 11 & 12 & 1.5 \\
\hline $\begin{array}{c}\text { Galvanized } \\
\text { steel }\end{array}$ & 210000 & 350 & 420 & 16 & -- & -- \\
\hline
\end{tabular}

2

14

\subsubsection{Concrete properties and pouring procedure}

4 The concrete used in the tested composite slabs was $C 25 / 30$ and therefore had a nominal resistance of $f_{c k}=25 \mathrm{~N} / \mathrm{mm}^{2}$. However, and in order to determine the actual resistance of the concrete poured in the slabs, common $\varnothing 15 \mathrm{~cm} \times 30 \mathrm{~cm}$ cylindrical specimens were prepared from the same structural concrete delivered for the slabs and had identical curing process as the slabs. These concrete specimens were tested in two sets of four specimens each: the first group was tested right before the first composite slab was conducted, while the second set was tested after the experimental programme was finished. The testing rate was the same for the two sets, $8.85 \mathrm{kN} / \mathrm{s}$, and the results obtained are summarized in Table 3, together with the calculated average strengths $f_{\mathrm{cm}}$. Table 3 Experimental results from tests on concrete specimens

\begin{tabular}{|c|c|c|c|c|}
\hline Test & Pouring date & $\begin{array}{l}\text { Test date } \\
\text { (48 days/ } \\
106 \text { days) }\end{array}$ & $\begin{array}{c}\text { Failure } \\
\text { load } \\
(\mathbf{k N})\end{array}$ & $\begin{array}{c}f_{\mathrm{c}} \\
\left(\mathbf{N} / \mathbf{m m}^{2}\right)\end{array}$ \\
\hline 1 & \multirow{4}{*}{ 10-jan-2013 } & \multirow{4}{*}{ 27-feb-2013 } & 586.6 & 33.2 \\
\hline 2 & & & 601.1 & 34.0 \\
\hline 3 & & & 597.9 & 33.8 \\
\hline \multirow[t]{2}{*}{4} & & & 588.0 & 33.3 \\
\hline & & & \multicolumn{2}{|c|}{ Average strength $f_{c m}=33}$. \\
\hline 1 & \multirow{4}{*}{ 10-jan-2013 } & \multirow{4}{*}{ 26-apr-2013 } & 679.7 & 38.5 \\
\hline 2 & & & 690.9 & 39.1 \\
\hline 3 & & & 674.4 & 38.2 \\
\hline 4 & & & 705.8 & 39.9 \\
\hline
\end{tabular}

According to EN 1994-1-1:2004 § B.3.3 (1) [1], decks were used in "as rolled" conditions during slab casting and were not subject to cleaning nor degreasing processes before the concrete was poured, with the aim of not modifying the normal friction and chemical bond conditions. Slabs were fully supported on the ground while the concrete 
1 was poured, since this is the most unfavourable situation for the shear bond mode of

2 failure (see Figure 5(a)), as required in EN 1994-1-1:2004 § B.3.3 (6) [1]. This

3 guaranteed that during the tests the effect of the dead weight of the slab will be totally

4 considered in the measured slips, and the concrete compaction was carried out through

5 an internal needle vibrator, as shown in Figure 5(c). Crack inducers (see Figure 5(a) and

6 (b)) were placed directly under the applied line loads to eliminate the tensile resistance

7 of the concrete. Right after pouring, an electro-welded reinforcing mesh was introduced

8 at a depth of $20 \mathrm{~mm}$ from the upper face to avoid any cracking effects due to shrinkage

9 (see Figure 5(d)), which also acted as reinforcement during lifting and transportation

10 against reversal bending moments.

11
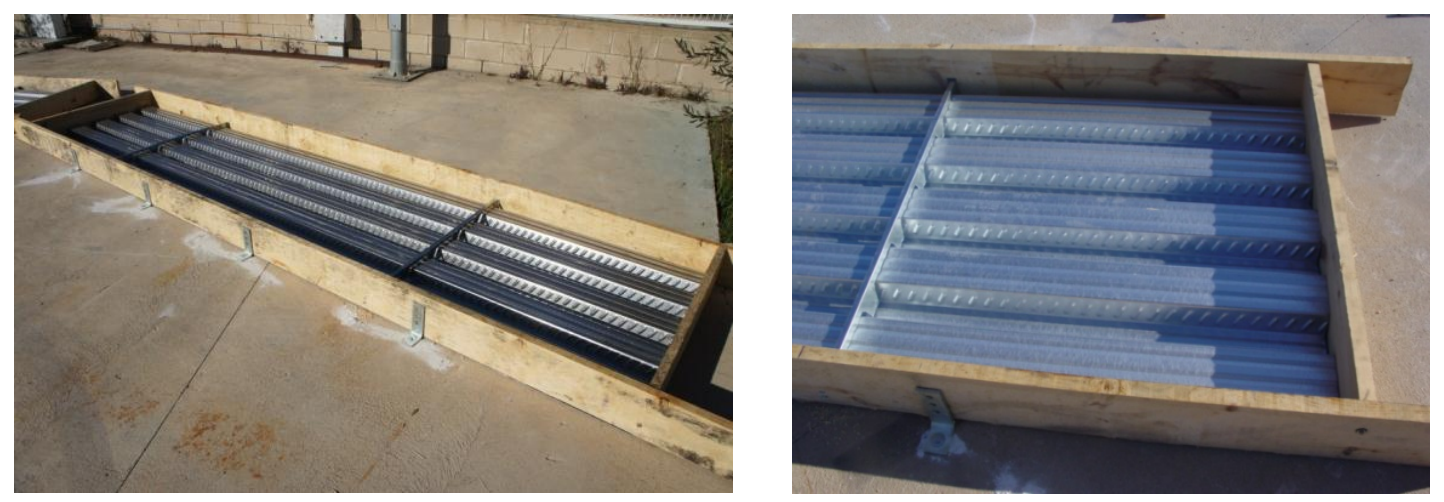

a) General view of the stainless steel deck

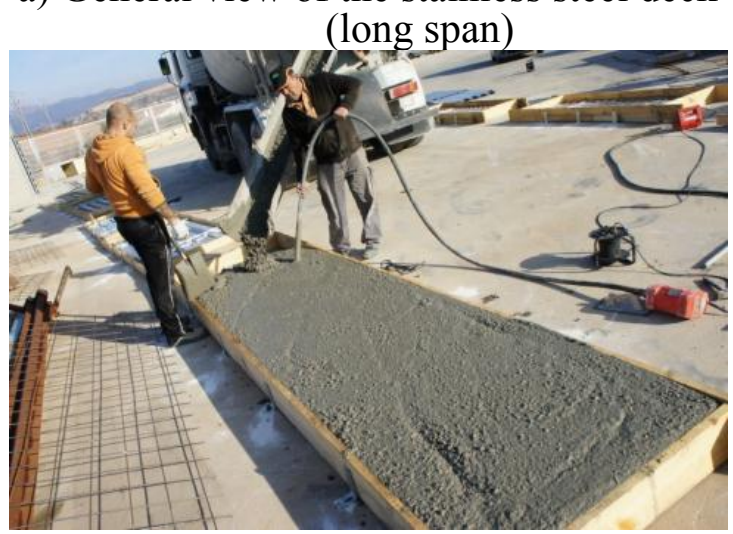

b) Detail of the crack inducer (short span)

c) Concrete compaction using a needle vibrator

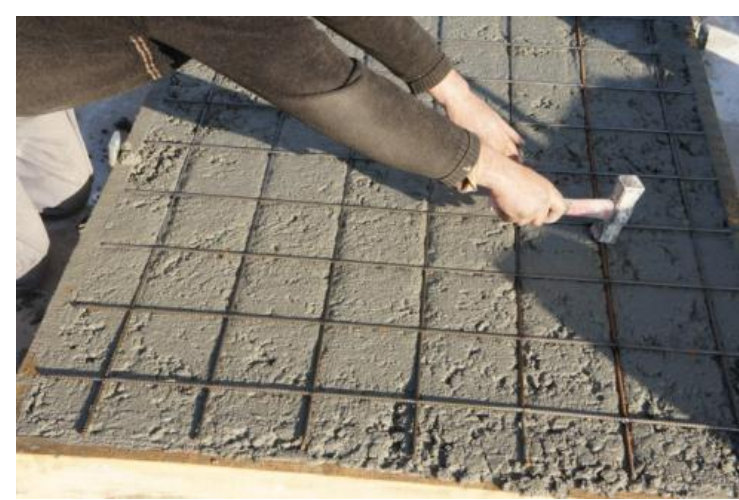

d) Superficial reinforcing mesh

Figure 5 Construction of the composite slab specimens 


\section{$1 \quad 2.2$ DESCRIPTION OF THE TESTS}

\section{$2 \quad 2.2 .1$ Design of specimens}

3 The experimental programme on ferritic stainless steel composite slabs was carried out

4 following the prescriptions given in EN 1994-1-1:2004, Annex B [1] and consisted of a

5 total of eight composite slab tests. Three long span composite slabs with ferritic

6 stainless steel decks and three with short span were tested, followed by two reference

7 tests on slabs with galvanized steel decks (one for long span and one for short span).

8 Table 4 presents a summary of the conducted tests, where the overall characteristics of

9 the considered slabs are reported. Note that the labelling of the specimen provides

10 information on the deck (C60), the material considered (SS for ferritic stainless steel

11 and CS for galvanized steel), the total length and total height of the specimens, and

12 finally, the number of each test.

13

Table 4 Summary of the experimental programme on composite slabs

\begin{tabular}{cccccc}
\hline Specimen & $\begin{array}{c}\text { Total } \\
\text { length } \\
{[\mathbf{m m}]}\end{array}$ & $\begin{array}{c}\text { Span } \\
\text { length } \\
{[\mathbf{m m}]}\end{array}$ & $\begin{array}{c}\text { Total } \\
\text { height } \\
{[\mathbf{m m}]}\end{array}$ & $\begin{array}{c}\text { Self- } \\
\text { weight } \\
{[\mathbf{k N}]}\end{array}$ & Test type \\
\hline C60-SS-4400-180-1 & 4400 & 4300 & 180 & 14.98 & static \\
C60-SS-4400-180-2 & 4400 & 4300 & 180 & 14.98 & cyclic + static \\
C60-SS-4400-180-3 & 4400 & 4300 & 180 & 14.98 & cyclic + static \\
C60-CS-4400-180 & 4400 & 4300 & 180 & 14.98 & static \\
\hline C60-SS-2600-100-1 & 2600 & 2500 & 100 & 3.95 & static \\
C60-SS-2600-100-2 & 2600 & 2500 & 100 & 3.95 & cyclic + static \\
C60-SS-2600-100-3 & 2600 & 2500 & 100 & 3.95 & cyclic + static \\
C60-CS-2600-100 & 2600 & 2500 & 100 & 3.95 & static \\
\hline
\end{tabular}

14

$15 \quad$ 2.2.2 Loading scheme

16 According to EN 1994-1-1:2004, Annex B [1], the test loading procedure is intended to

17 reproduce the loading applied over a period of time and it consists of two different

18 parts. In the initial part, slabs are subjected to cyclic loading, after which the slab is

19 loaded to failure under increasing load. In addition, if two groups of three tests are used,

20 as in this experimental programme, one of the three test specimens of each group should

21 be subjected just to static loading procedure without any cyclic loading in order to 
1 determine the level of the cyclic load for the other two. Therefore, this investigation

2 includes the initial static loading tests on long and short span slabs, which will define

3 the loading procedure to be used in the following cyclic tests.

4 The cycling loading varies between a minimum value $W_{\min }$ not greater than $0.2 W_{t}$

5 and a maximum value $W_{\max }$ not less than $0.6 \mathrm{~W}_{\mathrm{t}}$, according to $\mathrm{EN} 1994-1-1: 2004 \S$

6 B.3.4(3) [1], where $W_{t}$ is the maximum total load applied on the slabs, including the

7 measured applied load and the self-weight of the slab and the spread beams, determined

8 from the preliminary static tests. Considering this, and the total loads $W_{t}$ from the static

9 loading tests, the required limits for the cyclic tests are summarized in Table 5.

10 However, and as it can be observed in this table, the minimum load to be applied to long

11 slabs is lower than the self-weight, which is usual. Due to this fact and other

12 circumstances related to the hydraulic control system (minimum cylinder force around

$136.0 \mathrm{kN}$ ), the cyclic loadings of the slabs corresponded to those reported in Table 5 for

14 tests. Cyclic loading was applied for 5000 cycles following a sinusoidal signal $(0.5 \mathrm{~Hz})$.

15 Table 5 Summary of limits for cyclic loading in long and short span tests

\begin{tabular}{ccccccc}
\hline & $\begin{array}{c}\text { Self- } \\
\text { weight } \\
{[\mathrm{kN}]}\end{array}$ & $\begin{array}{c}\text { Load from } \\
\text { static test } \\
\boldsymbol{W}_{\boldsymbol{t}} \\
{[\mathrm{kN}]}\end{array}$ & $\begin{array}{c}\mathbf{0 . 2} \boldsymbol{W}_{\boldsymbol{t}} \\
{[\mathrm{kN}]}\end{array}$ & $\begin{array}{c}\mathbf{0 . 6} \boldsymbol{W}_{\boldsymbol{t}} \\
{[\mathrm{kN}]}\end{array}$ & $\begin{array}{c}\text { Min } \\
\boldsymbol{F}_{\text {load cell }}[\mathrm{kN}]\end{array}$ & $\begin{array}{c}\text { Max } \\
\boldsymbol{F}_{\text {load cell }} \\
{[\mathrm{kN}]}\end{array}$ \\
\hline $\begin{array}{c}\text { Long slab } \\
\text { (required) }\end{array}$ & 15.0 & 42.3 & 8.5 & 25.4 & -- & 9.9 \\
$\begin{array}{c}\text { Short slab } \\
\text { (required) }\end{array}$ & 3.9 & 39.5 & 7.9 & 23.7 & 3.5 & 19.3 \\
\hline $\begin{array}{c}\text { Long slab } \\
\text { (test) }\end{array}$ & 15.0 & -- & 22.2 & 26.5 & 6.7 & 10.5 \\
$\begin{array}{c}\text { Short slab } \\
\text { (test) }\end{array}$ & 3.9 & -- & 11.4 & 23.4 & 7.0 & 19.0 \\
\hline
\end{tabular}

16

17 The adopted test setups for long and short slabs were defined according to

18 EN 1994-1-1:2004 [1] and are presented in Figures 6 and 7, where the adopted $L_{\text {load }}$ and

$19 L_{s}$ distances were $2150 \mathrm{~mm}$ and $1075 \mathrm{~mm}$ for long slab tests and $1250 \mathrm{~mm}$ and $625 \mathrm{~mm}$

20 for short slabs. The applied load was transmitted to the slabs through two HEB beams

21 and a $100 \mathrm{~mm}$ width neoprene pad placed on a sand layer, as shown in Figure 8(b), 
1 which guaranteed a uniformly distributed load. Slabs were simply supported, with

2 boundary conditions consisting of one fixed and one roller supports. This arrangement

3 provides a constant shear force between the point of load application and the point of

4 support, while a pure bending moment loading is achieved at the central span, although

5 the dead weight of the slab slightly modifies these concepts.

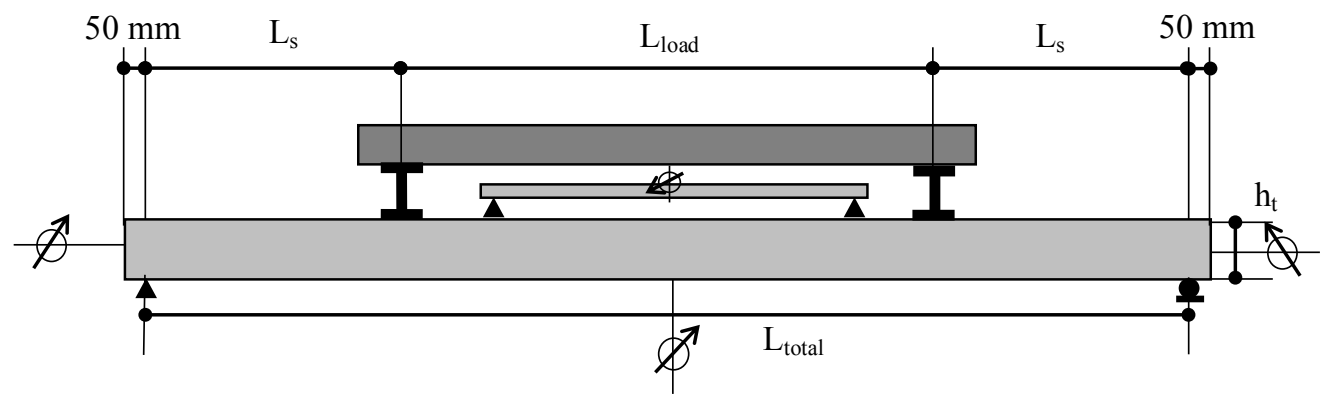

Figure 6 Definition of composite slab tests

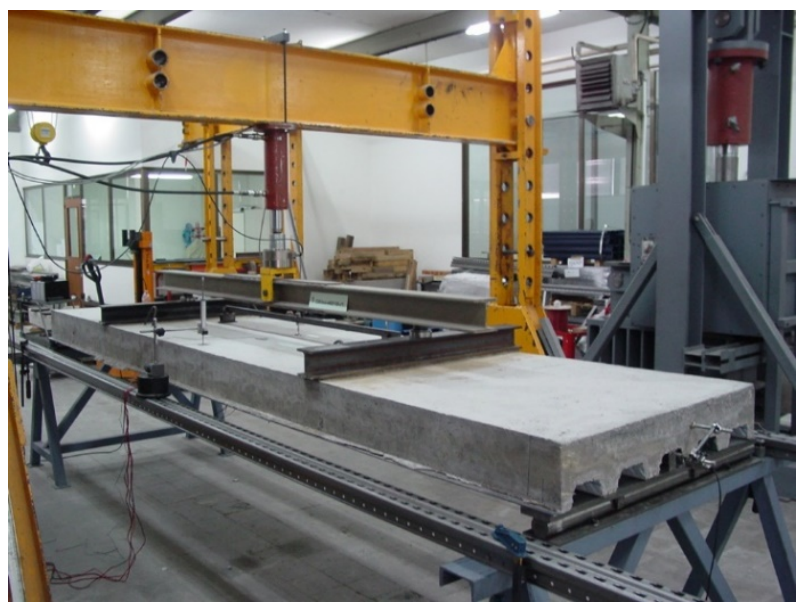

Figure 7 General view of the experimental setup for composite slabs

6

7

8

9

\subsubsection{Layout of measurements}

Applied loads were measured by means of a load cell and the C60-SS-4400-180-3 specimen was instrumented with strain gauges, which was tested using a reduced cycling loading to produce the expected initial slip and cracking. Slabs were instrumented with several linear displacement transducers measuring deflections at midspan sections, as well as the relative slip of the concrete and the deck at each slab end, as the rotation of the slab end will add difficulty to measure the slip along the slab 
1 axis (as shown in Figure 8(a)). In addition, a final transducer was incorporated to a

2 central curvature measurement device (see Figures 6 and 8(b)-(c)) in order to measure

3 initial cracking of the slab due to pure bending.

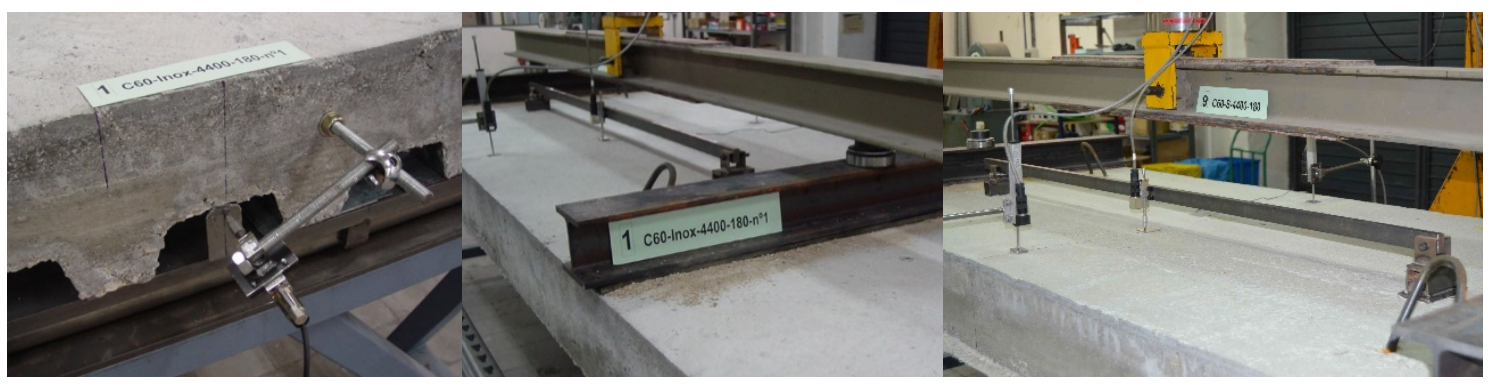

a) Detail of the transducer measuring longitudinal slip b) Uniform load distribution on the sand layer c) Setup for curvature measurement

Figure 8 Details of the experimental setup for composite slabs

All displacement transducers were set to zero after all test elements were arranged so the effect of the self-weight of the slabs and spreader beams was not included in the measured displacements. In a similar way, the load cell was set to zero while holding the load distribution system so the weight was already included in the load cell output.

\section{EXPERIMENTAL RESULTS}

This section presents the results of the conducted tests on composite slabs with ferritic stainless steel and galvanized steel decks. Results are summarized in tables for long and short span slabs, and curves showing the load-misdspan deflection and loadlongitudinal slip relationships are also reported, as well as figures illustrating the failed slabs. The failure of all tested slabs was clearly due to longitudinal shear, since a very significant relative slip between the deck and the concrete was observed. It is also worth noting that the break of the chemical bond and the first slip occurred early at both sides of the slabs at the very beginning of the first loading ramp for all specimens. Moreover, the significant permanent deflections and slips were completely developed at the first load cycle as well, without any variation in the subsequent 5000 cycles. These 
1 permanent values correspond to the initial slip and deflection values of the response

2 curves showed in next figures.

3 In order to determine whether each slab showed a ductile or brittle behaviour, the

4 failure loads have been compared to the reference loads causing an end slip of $0.1 \mathrm{~mm}$, 5 as provided in EN 1994-1-1:2004 § 9.7.3(3) [1]. Since the failure loads exceeded the 6 corresponding reference loads by more than the specified $10 \%$, all tested slabs can be 7 classified as ductile. It should be noted that according to EN 1994-1-1:2004 [1] the 8 failure load of the slab corresponds to the maximum applied load, provided that the 9 midspan deflection is lower than 1/50 of the span length. For long slabs, this limitation 10 had no effect in the definition of the failure load, although for short slabs the restriction 11 lightly affected the maximum load to be considered in this classification. This is 12 explained by the relative slenderness of the studied slabs, given that the height of long 13 slabs was $180 \mathrm{~mm}$ while short slabs showed a total height equal to $100 \mathrm{~mm}$.

14 Experimental results corresponding to long and short span slab tests are reported in 15 Table 6 , where the measured loads at $0.1 \mathrm{~mm}$ and $0.5 \mathrm{~mm}$ slips $F_{0.1 \mathrm{~mm}}$ and $F_{0.5 \mathrm{~mm}}$ are 16 provided in addition to the achieved maximum loads $F_{u}$ in order to evaluate the ductile 17 behaviour of the slabs and whether the slip needs to be accounted for in the 18 determination of deflections. Midspan displacements $\delta_{u}$ and the longitudinal slips at the 19 failed slab end are also reported. The failure of the long slabs was caused by the slip of 20 one of the ends due to significant cracking of the slabs, as shown in Figure 9. 


\begin{tabular}{cccccc}
\hline \multirow{2}{*}{ Specimen } & \multicolumn{3}{c}{ Load cell Force } & \multicolumn{2}{c}{ Displacements at $\boldsymbol{F}_{\boldsymbol{u}}$} \\
\cline { 2 - 6 } & $\begin{array}{c}F_{0.1 \mathrm{~mm}} \\
{[\mathrm{kN}]}\end{array}$ & $\begin{array}{c}F_{0.5 m m} \\
{[\mathrm{kN}]}\end{array}$ & $\begin{array}{c}F_{u} \\
{[\mathrm{kN}]}\end{array}$ & $\begin{array}{c}\boldsymbol{\delta}_{u} \\
{[\mathrm{~mm}]}\end{array}$ & $\begin{array}{c}\text { Slip } \\
{[\mathrm{mm}]}\end{array}$ \\
\hline C60-SS-4400-180-1 & 6.8 & 6.8 & 26.9 & 42.1 & 6.1 \\
C60-SS-4400-180-2 & $<10.0$ & $<10.0$ & 29.9 & 38.9 & 3.5 \\
C60-SS-4400-180-3 & 5.0 & 6.9 & 32.6 & 43.5 & 7.1 \\
C60-CS-4400-180 & 25.4 & 25.4 & 31.6 & 31.7 & 4.4 \\
\hline C60-SS-2600-100-1 & 3.6 & 9.8 & 34.5 & 35.1 & 52.6 \\
C60-SS-2600-100-2 & 3.5 & 9.9 & 36.7 & 39.5 & 70.7 \\
C60-SS-2600-100-3 & 4.4 & 7.9 & 34.9 & 36.2 & 66.8 \\
C60-CS-2600-100 & 23.5 & 20.0 & 34.2 & 36.1 & 75.2 \\
\hline
\end{tabular}

2

3
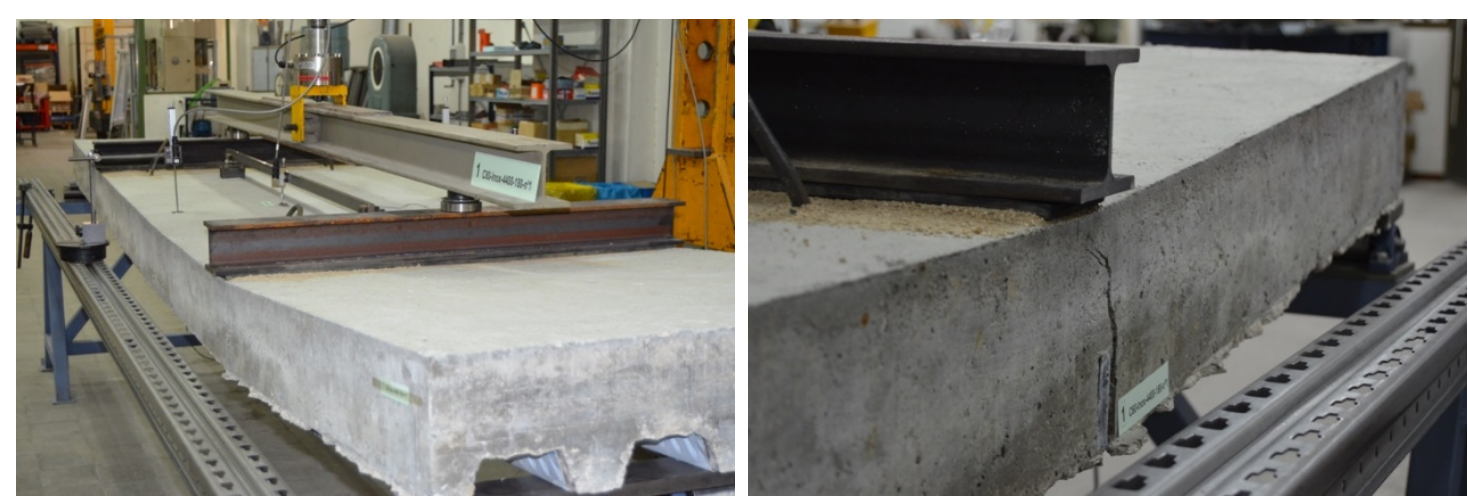

Figure 9 Long slabs after slip failure

4

5 The load-deflection curves measured in the long slabs are presented in Figure 10, where

6 the average deflections of the midspan section are plotted, whereas Figure 11 shows the

7 load-longitudinal slip curves for the same specimens. In both figures, cyclic residual

8 deflections and slips have been included. The different performance of ferritic stainless

9 steel and galvanized steel slabs is worth mentioning, although the detailed analysis is

10 given in Section 4. As it can be appreciated in these figures, the initial slip of cycled

11 specimens (\#2 and \#3) are similar for both slab lengths (below $2 \mathrm{~mm}$, see Figures 11

12 and 14), although the relative dispersion is higher in the case of long slabs than for the

13 short ones. Note that this higher slip dispersion in long slabs is magnified in terms of

14 mid-span deflections (Figure 10). 


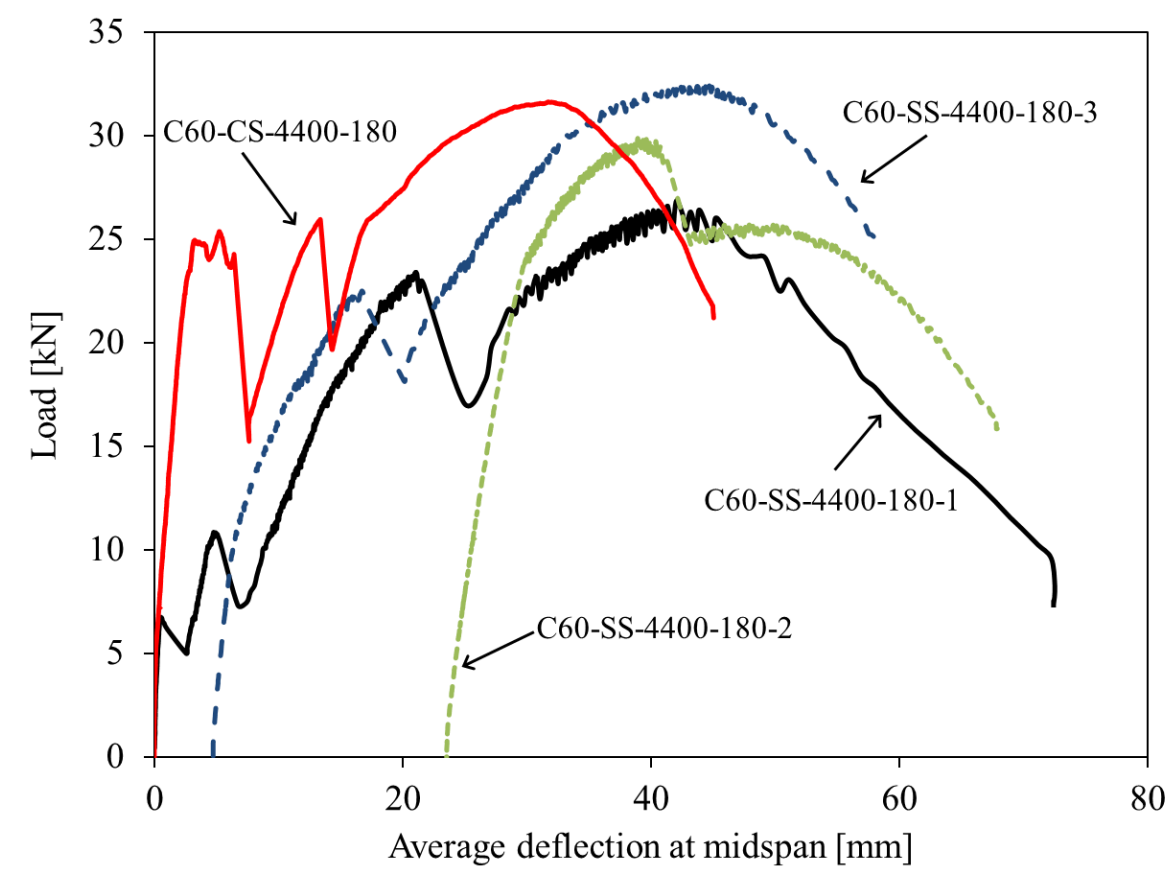

Figure 10 Load-midspan deflection curves for long span slab tests (cycling residual deflections included)

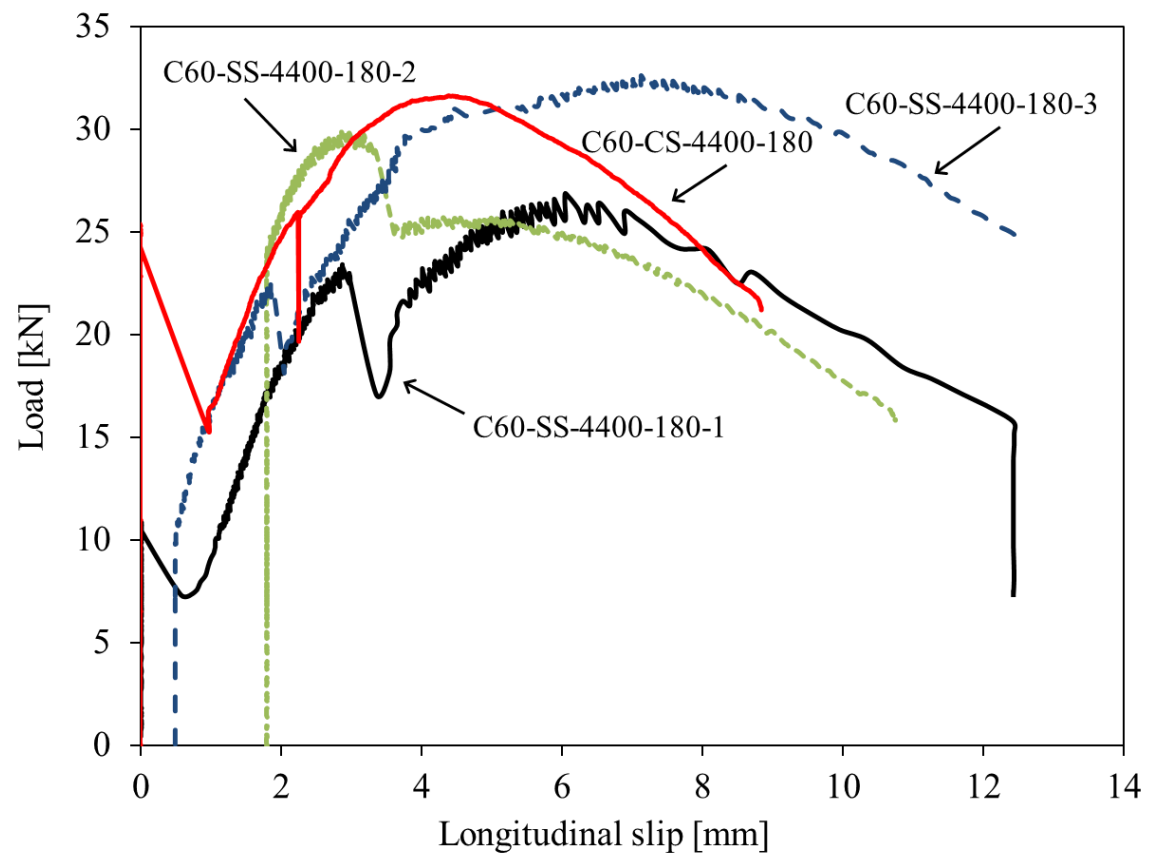

Figure 11 Load-slip curves for long span slab tests (cycling residual deflections included)

2 Figure 12 shows one of the short slabs after longitudinal shear failure, while the load-

3 deflection curves corresponding to the tested short slabs are presented in Figure 13 and

4 the load-longitudinal slip curves are shown in Figure 14 for the same specimens. 
1
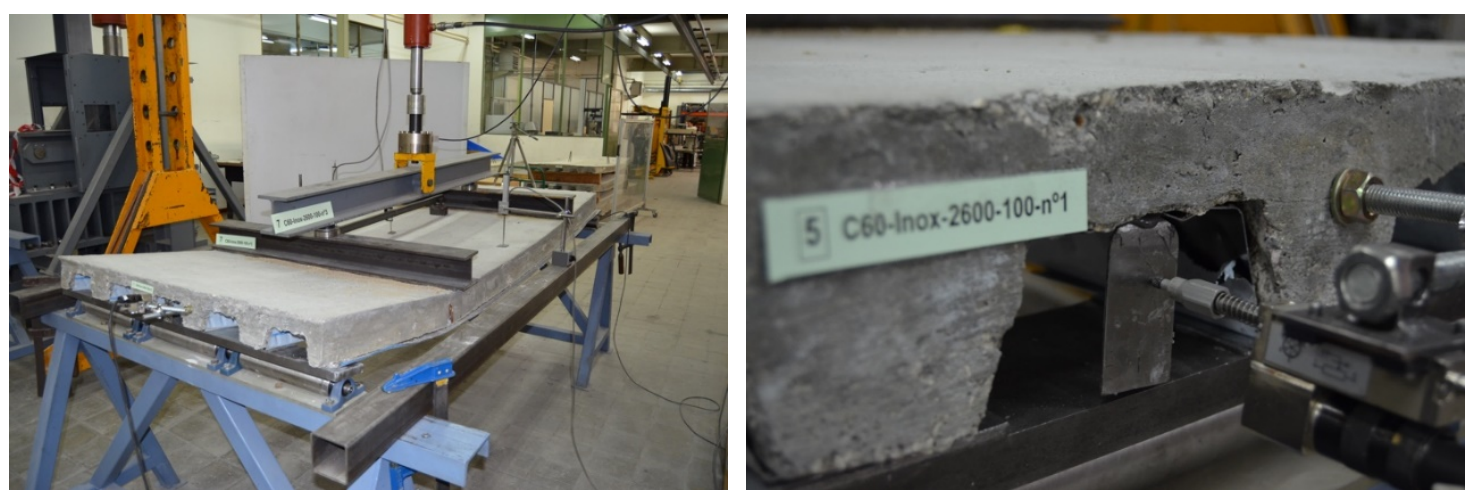

Figure 12 Short slab after longitudinal shear failure

2

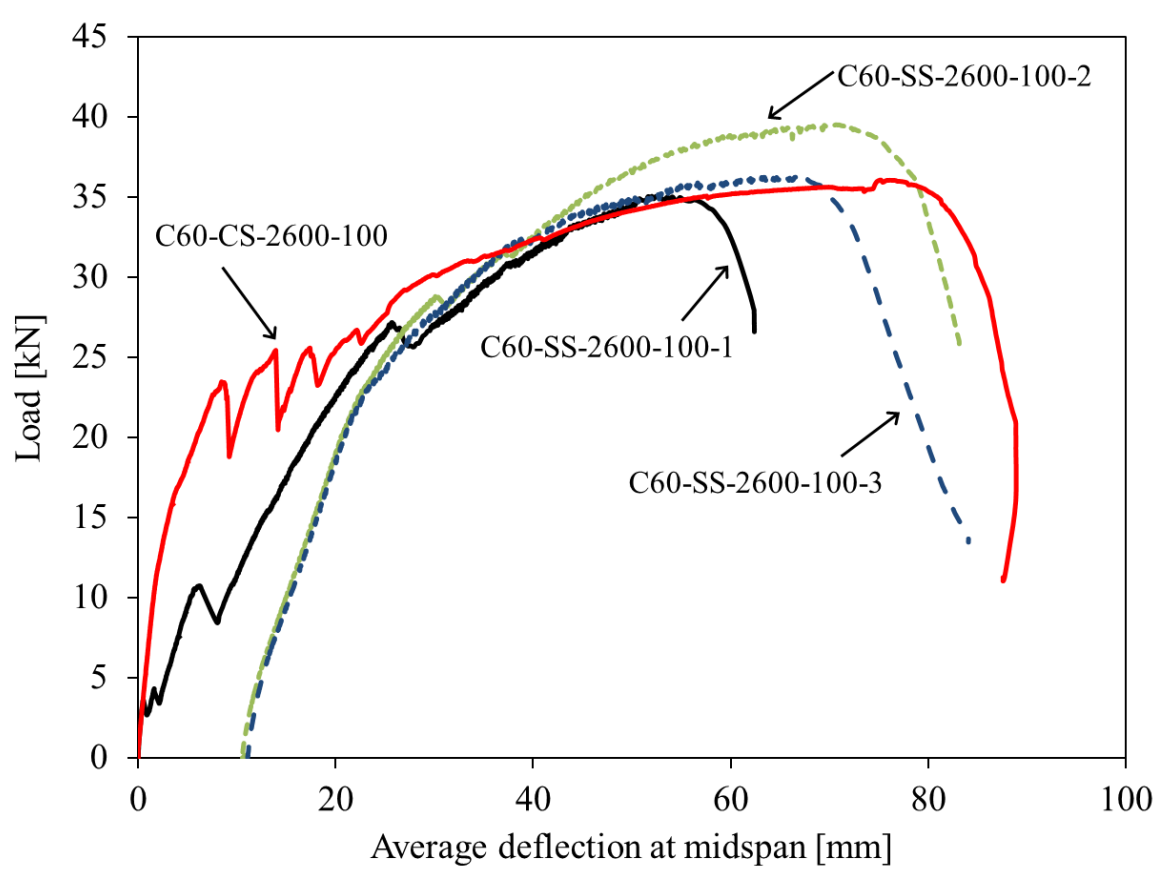

Figure 13 Load-midspan deflection curves for short span slab tests (cycling residual deflections included) 


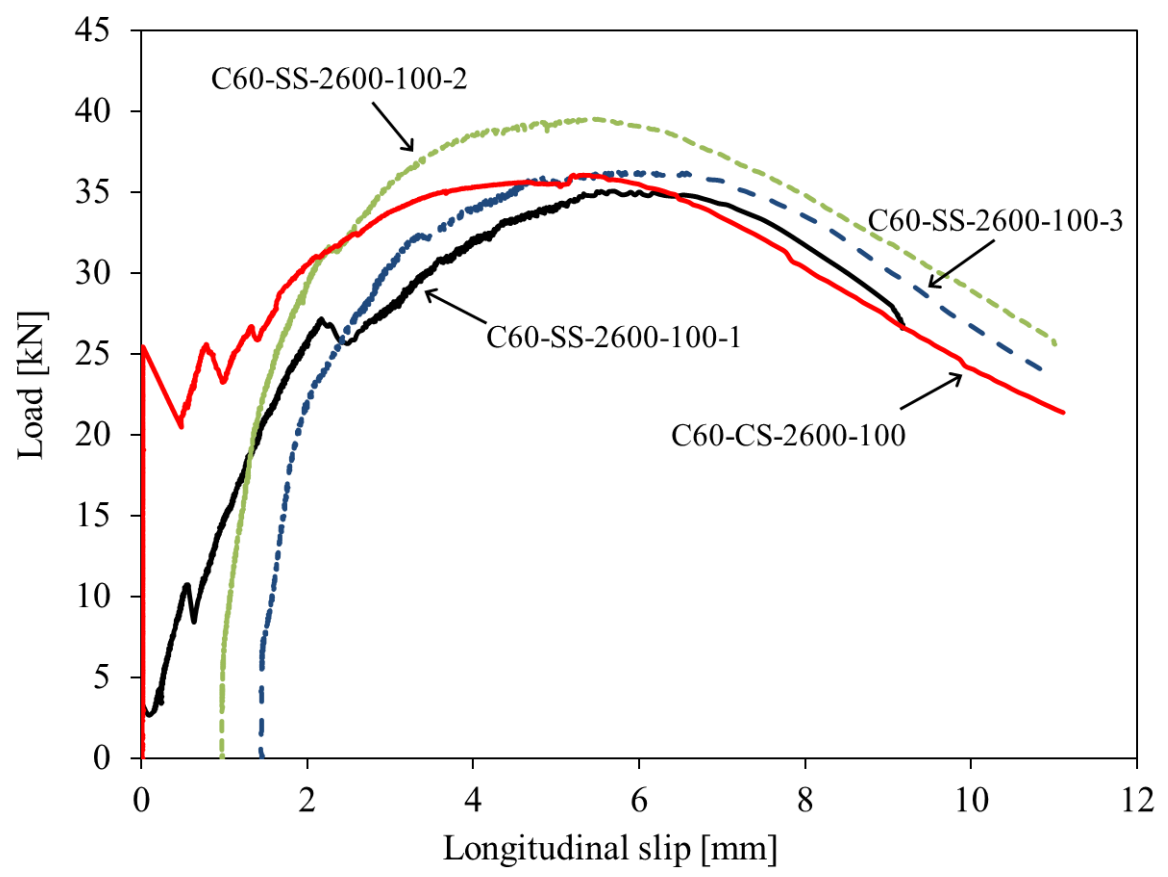

Figure 14 Load-slip curves for short span slab tests (cycling residual deflections included)

1

2 As mentioned before, the objective of conducting a preliminary cyclic loading in composite

3 slabs is to eliminate the chemical bond between the steed deck and the concrete. As no

4 noticeable differences are observed in reached ultimate loads (the ultimate load corresponding

5 to cycled specimens are even higher sometimes) it can be highlighted that the ultimate loads

6 do not depend on the initial chemical bond. Moreover, in this case, the chemical bond

7 between the stainless steel deck and the concrete is very low or even inexistent. This will be

8 investigated and commented more in detail in the following sections, to evaluate the influence

9 of the chemical composition of the steel and the superficial roughness in this chemical bond.

11 Results obtained from the conducted experimental programme on ferritic stainless steel 12 composite slabs can be used to determine the design parameters according to 13 EN 1994-1-1:2004 [1], which will allow similar composite slabs to be designed in the 14 future. Since all slabs failed due to longitudinal shear, the two methodologies included 
1 in EN 1994-1-1:2004 [1] for this failure mode have been investigated in this section, the

$2 m-k$ Method and the Partial Connection Method.

3 4.1 THE $m-k$ METHOD

4 The $m-k$ Method is a semi-empiric design method for composite slabs with 5 embossments based on the assumption that the ultimate shear force is linearly 6 dependent on $1 / L_{s}$, where $L_{s}$ is the shear span length, in which the shear resistance is 7 determined by means of slab tests. Thus, for the estimation of the $m$ and $k$ parameters 8 defining the longitudinal shear failure mode, two groups of slabs showing different 9 shear span lengths are required. In this method, the design shear resistance $V_{l, R d}$ given in 10 Eq. (1) is determined from the $m$ and $k$ parameters, as shown in Figure 2. In this 11 expression, $b$ and $L_{s}$ are the slab width and shear span length of the slab, $d_{p}$ is the 12 distance between the centroidal axis of the profiled steel deck and the extreme fibre of the composite slab in compression, $A_{p}$ is the cross-sectional area of profiled steel deck and $\gamma_{V S}$ is the partial factor for design shear resistance of a composite slab.

$$
\mathrm{V}_{\mathrm{Ed}} \leq \mathrm{V}_{l, R d}=\frac{b d_{p}\left(\frac{m A_{p}}{b L_{s}}+k\right)}{\gamma_{V S}}
$$

For the determination of the $m$ and $k$ parameters, both long and short span slabs have 17 been considered and experimental results have been plotted in the $18 V_{t} /\left(b \cdot d_{p}\right)-A_{p} /\left(b \cdot L_{s}\right)$ diagram, as shown in Figure 15. Support reactions $V_{t}$ have 19 been calculated as $V_{t}=W_{t} / 2$ and since all specimens showed a ductile behaviour, no 20 reduction was applied. According to EN 1994-1-1:2004 $§ 9.7 .3$ and B.3.5 [1], the $m$ and $21 k$ parameters defining the longitudinal shear failure can be estimated from the experimental results provided that the deviation of these results is less than $10 \%$ of the average value, which Tables 6 proofs to be satisfied. Thus, the characteristic values of 24 each slab group are obtained by reducing in a $10 \%$ the corresponding lowest value, 
1 resulting in $m=134 \mathrm{~N} / \mathrm{mm}^{2}$ and $k=-0.0329 \mathrm{~N} / \mathrm{mm}^{2}$, as represented in Figure 15. It

2 should be pointed that such negative $k$ values are commonly obtained in some cases,

3 typically in open-rib profiles or when lightweight concrete is used [32].

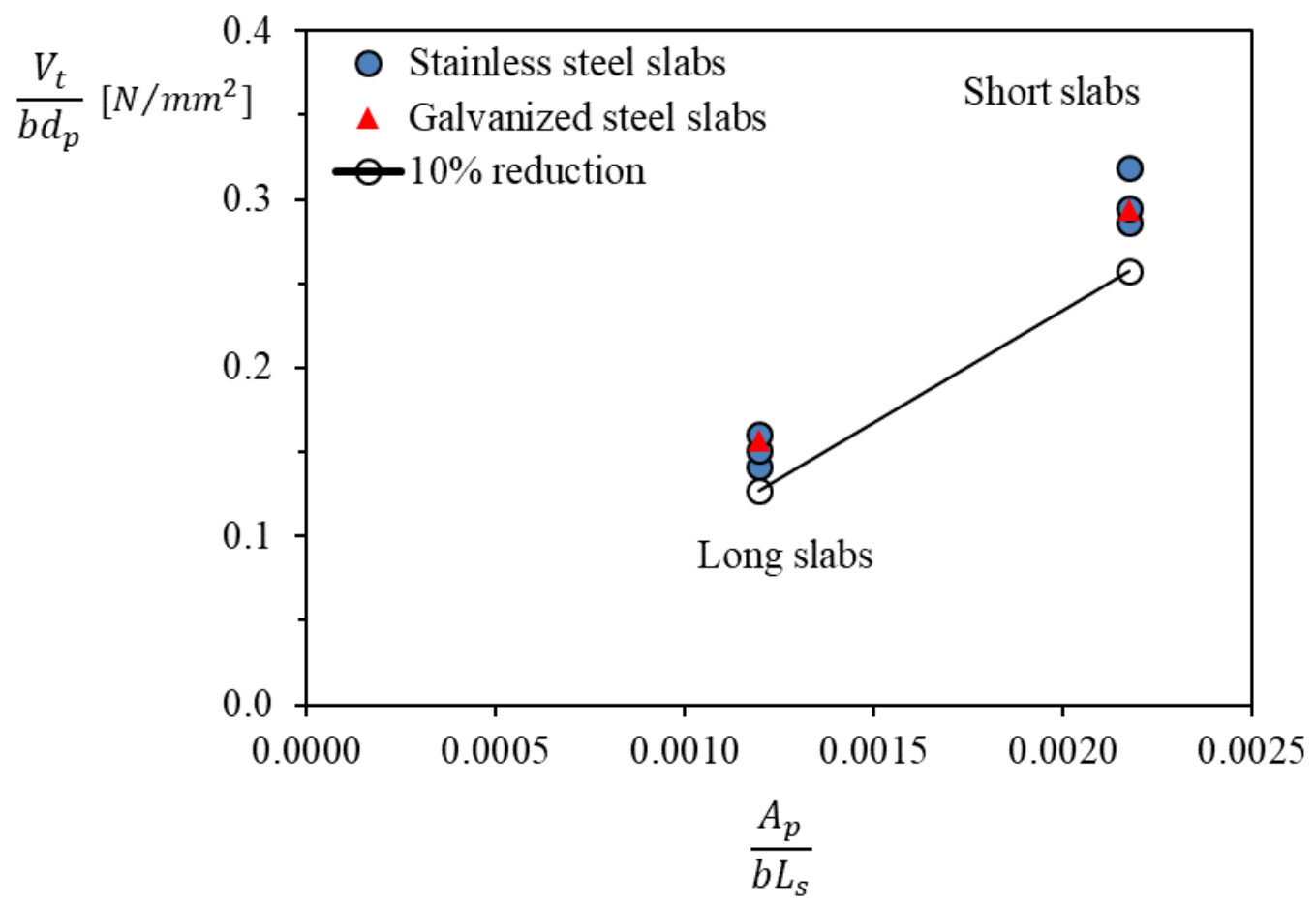

Figure 15 Linear interpolation defining the longitudinal shear failure mode for ferritic stainless steel specimens

4

\subsection{THE PARTIAL CONNECTION METHOD}

The Partial Connection Method determines the degree of connection corresponding to

each of the tested composite slabs, which ranges between the two extreme situations,

the full connection $(\eta=1)$ where the plastic bending moment of the composite section is

reached, and the situation with no connection $(\eta=0)$, where only the plastic efficient bending moment of the steel deck is considered. Between these limits, EN 1994-11:2004 [1] considers an interpolation model assuming that in partial interaction the slip behaviour is ductile enough to let both materials reach their ultimate capacity.

The degree of shear connection $\eta$ is defined as the ratio between the concrete compression force at partial connection $N_{c}$ and at full connection $N_{c, f}$, as given in 
1 Eq. (2), where $f_{y p, d}$ is the design value of the yield strength of the profiled steel deck,

$2 \tau_{u, R d}$ is the design value of the longitudinal shear strength and $L_{x}$ is the distance from a

3 cross-section to the nearest support. The stress diagram of the composite section

4 corresponding to the partial connection ultimate limit state is presented in Figure 16.

$$
\eta=\frac{N_{\mathrm{c}}}{N_{\mathrm{c}, \mathrm{f}}}=\frac{N_{\mathrm{c}}}{A_{\mathrm{pe}} f_{\mathrm{yp}, \mathrm{d}}}=\frac{\tau_{\mathrm{u}, \mathrm{Rd}} b L_{x}}{A_{\mathrm{pe}} f_{\mathrm{yp}, \mathrm{d}}}
$$

5
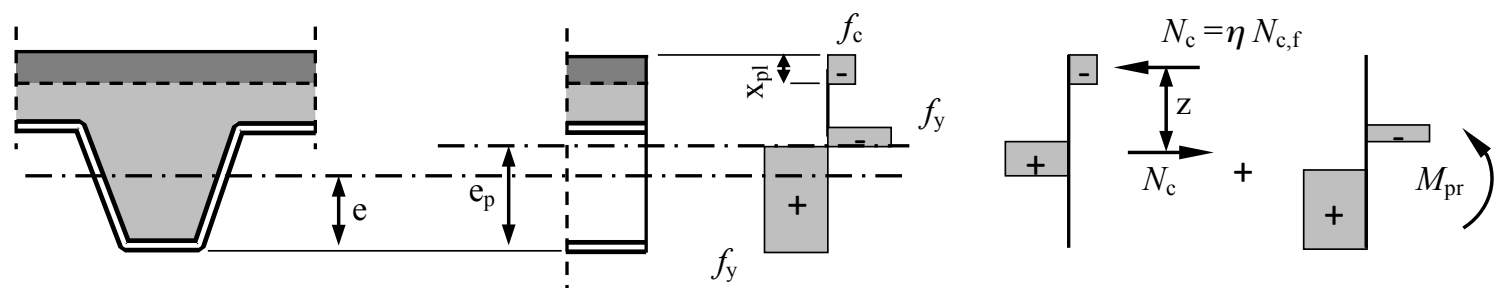

Figure 16 Stress distribution in sagging bending in partial connection

6

7

8

11 The design value of the shear resistance $\tau_{u, R d}$ can be determined from a series of three resistance $\tau_{u, R d}$, and provided that they showed longitudinal shear failure modes, an

17 additional value of $\tau_{u, R d}$ has been calculated for comparison purposes. composite slab tests and slabs of one single span are sufficient according to EN 1994-1-1:2004 [1]. However, EN 1994-1-1:2004 [1] establishes that the span length should be as long as possible, provided that the slab will fail due to longitudinal shear. Although the short span slab tests are not necessary for the determination of the shear 
1 From the equations listed above and considering the measured mean strength values

2 for the ferritic stainless steel decks and concrete, the partial interaction diagram of the

3 studied slabs can be derived. According to EN 1994-1-1:2004 § B.3.6 (2) and (3) [1],

4 the partial connection degree $\eta$ and the ultimate shear stresses $\tau_{u, R d}$ can be then obtained

5 from the measured ultimate bending moment of each test, as for Eq. (6), $L_{0}$ is the length

6 of overhang $\left(L_{0}=50 \mathrm{~mm}\right), \mu$ is the default value of friction coefficient (if taken into

7 account, the recommended value is $\mu=0.5)$ and $V_{t}$ is the reaction at the support. The

8 partial connection degree $\eta$ can be directly calculated by solving the quadratic equation

9 given in Eq. (7) and once $\tau_{u}$ values are determined, the characteristic $\tau_{u, R k}$ and the design

10 values $\tau_{u, R d}$ can be easily derived.

$$
\begin{gathered}
\tau_{\mathrm{u}}=\frac{\eta N_{\mathrm{c}, \mathrm{f}}-\mu V_{\mathrm{t}}}{b\left(L_{\mathrm{x}}+L_{0}\right)} \\
M_{\mathrm{u}, \text { test }}=\eta N_{\mathrm{c}, \mathrm{f}} \cdot\left(h-0,5 \eta x_{\mathrm{pl}, \mathrm{f}}-e_{\mathrm{p}}+\left(e_{\mathrm{p}}-e\right) \eta\right)+1,25 M_{\mathrm{pa}}(1-\eta)
\end{gathered}
$$

11 From the equations presented above and for the ultimate bending moments 12 corresponding to the failure loads of the ferritic stainless steel composite slab tests, the 13 following ultimate shear stresses $\tau_{u, R d}$ can be derived. In this study, the $M_{p a}$ value 14 obtained from the previous experimental programme on ferritic stainless steel decks in 15 construction stage by Arrayago et al. [18] has been considered. Results accounting for 16 the additional longitudinal shear resistance caused by the support reactions are 17 presented in Table 7, together with those corresponding to the ultimate shear stresses 18 without considering the effect of the support reaction. The characteristic shear strengths $19 \tau_{u, R k}$ have been calculated from the test values as the $5 \%$ fractiles using an appropriate 20 statistical model in accordance with EN 1990:2005, Annex D [33], and the design 21 strengths $\tau_{u, R d}$ have been then obtained as the characteristic strengths divided by the $\gamma_{V S}$ 
1 partial safety factor $\left(\gamma_{V S}=1.25\right.$ as recommended in EN 1994-1-1:2004 [1]). Results in

2 Table 7 indicate that the derived ultimate shear stresses are very similar for ferritic

3 stainless steel and galvanized steel decks, showing an equivalent response at failure.

4 These values are also comparable to those reported by Lauwens et al. [31] for tests

5 on composite slabs with ferritic stainless steel trapezoidal decks. For this experimental

6 programme the same Cofraplus60 cross-section made from ferritic stainless steel grade

7 EN1.4003 was considered, although the tested span lengths and total slab heights were

8 slightly different. All slabs reported in [31] were $100 \mathrm{~mm}$ high, and while three tests

9 were conducted for a span length of $1800 \mathrm{~mm}$, a single slab was tested with a $1300 \mathrm{~mm}$

10 span length. For the short specimen a design ultimate shear stress $\tau_{u, R d}$ accounting for

11 the effect of the support reaction equal to $0.293 \mathrm{~N} / \mathrm{mm}^{2}$ was derived, while for the long

12 specimens $\tau_{\mathrm{u}, \mathrm{Rd}}$ was $0.194 \mathrm{~N} / \mathrm{mm}^{2}$ in [31]. This last design ultimate shear stress is

13 comparable to that obtained for the short specimens in the present experimental

14 programme, $0.167 \mathrm{~N} / \mathrm{mm}^{2}$, since the adopted slab height are the same, with

15 considerably similar span lengths. Calculated shear stress values are similar, being those

16 corresponding to slabs with $\mathrm{L}=2600 \mathrm{~mm}$ lower since they are longer than those

17 reported in [31]. 


\begin{tabular}{|c|c|c|c|c|c|c|c|c|c|}
\hline & \multirow{2}{*}{ Specimen } & \multirow{2}{*}{$\begin{array}{c}M_{u, \text { test }} \\
{[\mathrm{kNm}]}\end{array}$} & \multirow{2}{*}{$\eta=N_{c} / N_{c, f}$} & \multicolumn{3}{|c|}{$\begin{array}{l}\text { Accounting for the effect of the } \\
\text { support reaction }\end{array}$} & \multicolumn{3}{|c|}{$\begin{array}{c}\text { Without accounting for the effect } \\
\text { of the support reaction }\end{array}$} \\
\hline & & & & $\begin{array}{c}\tau_{u} \\
{\left[\mathrm{~N} / \mathrm{mm}^{2}\right]}\end{array}$ & $\begin{array}{c}\tau_{u, R k} \\
{\left[\mathrm{~N} / \mathrm{mm}^{2}\right]}\end{array}$ & $\begin{array}{c}\tau_{u, R d} \\
{\left[\mathrm{~N} / \mathrm{mm}^{2}\right]}\end{array}$ & $\begin{array}{c}\tau_{u} \\
{\left[\mathrm{~N} / \mathrm{mm}^{2}\right]}\end{array}$ & $\begin{array}{c}\tau_{u, \mathrm{Rk}} \\
{\left[\mathrm{N} / \mathrm{mm}^{2}\right]}\end{array}$ & $\begin{array}{c}\tau_{u, R d} \\
{\left[\mathrm{~N} / \mathrm{mm}^{2}\right]}\end{array}$ \\
\hline \multirow{4}{*}{$\begin{array}{l}\text { Long } \\
\text { slabs }\end{array}$} & C60-SS-4400-180-1 & 21.16 & 0.442 & 0.113 & \multirow{3}{*}{0.114} & \multirow{3}{*}{0.092} & 0.123 & \multirow{3}{*}{0.124} & \multirow{3}{*}{0.100} \\
\hline & C60-SS-4400-180-2 & 22.65 & 0.485 & 0.125 & & & 0.135 & & \\
\hline & C60-SS-4400-180-3 & 24.03 & 0.524 & 0.135 & & & 0.146 & & \\
\hline & C60-CS-4400-180 & 23.54 & 0.506 & 0.133 & 0.133 & 0.106 & 0.144 & 0.144 & 0.115 \\
\hline \multirow{4}{*}{$\begin{array}{l}\text { Short } \\
\text { slabs }\end{array}$} & C60-SS-2600-100-1 & 10.85 & 0.459 & 0.208 & \multirow{3}{*}{0.209} & \multirow{3}{*}{0.167} & 0.224 & \multirow{3}{*}{0.225} & \multirow{3}{*}{0.180} \\
\hline & C60-SS-2600-100-1 & 12.08 & 0.565 & 0.258 & & & 0.276 & & \\
\hline & C60-SS-2600-100-1 & 11.18 & 0.488 & 0.222 & & & 0.238 & & \\
\hline & C60-CS-2600-100 & 11.13 & 0.494 & 0.229 & 0.229 & 0.183 & 0.246 & 0.246 & 0.197 \\
\hline
\end{tabular}




\subsection{COMPARISON OF STAINLESS STEEL AND GALVANIZED STEEL SLABS}

2 From the comparison of the experimental results for ferritic stainless steel and

3 galvanized steel composite slabs, it can be seen that differences on the ultimate loads

4 are not appreciable. Thus, differences between the parameters governing the Ultimate

5 Limit State (ULS) are not significant regardless the considered design method. Both the

$6 \quad m-k$ Method and the Partial Connection Method provide similar results when applied to

7 slabs with ferritic stainless steel or galvanized steel decks.

8 However, from the comparison of the results corresponding to slabs with ferritic

9 stainless steel and galvanized steel decks in Figures 11-14 it can be concluded that

10 stainless steel decks show a considerably lower resistance to first slip $(>0.1 \mathrm{~mm})$ than

11 slabs with conventional galvanized steel. The weaker initial adherence is attributed to

12 the much smoother surface of the stainless steel deck and also to the different chemical

13 reactions between the concrete and stainless steel or zinc surfaces. Regarding the

14 Serviceability Limit State (SLS), the low resistances corresponding to the $0.5 \mathrm{~mm}$ slips

15 (see $\mathrm{F}_{0.5 \mathrm{~mm}}$ values in Table 6) exhibited by ferritic stainless steel decks might make

16 necessary to provide end anchors or to consider the slip effect when calculating

17 deflections under service loads, as established in EN 1994-1-1:2004 § 9.8.2(7) [1].

18 Other design provisions, such as the French National Annex, NF EN1994-1-1/NA by

19 Commission de normalisation de la construction mixte CNCMIX [34] and the technical

20 advice for composite slabs in Commission chargée de formuler des Avis Techniques

21 [35], are even more restrictive in terms of Serviceability Limit State and limit the first 22 slip of slabs to $0.1 \mathrm{~mm}$.

23 Ertzibengoa et al. [36] studied the influence of the material and its roughness in the

24 steel-concrete bond by conducting several push-out tests on carbon steel and two 25 different grades of austenitic and ferritic stainless steel rebars. In [36], the authors 
1 concluded that the factors affecting the concrete-steel adhesion behaviour are the

2 geometry, the material type and the micro-roughness $\left(\mathrm{R}_{\mathrm{a}}\right)$. According to [36], the

3 influence of the material on the developed bond capacity is more relevant for smooth

4 samples (without any rib or macroscopic roughness) than for ribbed ones, since the

5 bond behaviour in smooth samples is primarily governed by the chemical adhesion

6 mechanism. It was observed that the bond strength can be around $85 \%$ higher in carbon

7 steel than in austenitic stainless steel due to the different material type, while the ferritic

8 grade showed a much lower bond strength. The authors in [36] also studied the

9 influence of the roughness in the bond strength by analysing the same austenitic

10 stainless steel grade with two different surface finishes. The study concluded that a $\mathrm{R}_{\mathrm{a}}$

11 variation from $3 \mu \mathrm{m}$ to $0.4 \mu \mathrm{m}$ results in a $20 \%$ bond strength reduction. Considering

12 that the tested specimens involved galvanized steel and ferritic stainless steel decks, the

13 different behaviour of the slabs obtained in this present study is consistent with the

14 results published by [36]. With the aim of measuring these effects, this paper presents

15 an additional study on the deck-concrete bond. The experimental results presented in the

16 previous sections highlighted the different bond strength of galvanized and stainless

17 steel decks with identical geometries.

18 Roughness tests were performed by the deck producer in galvanized and ferritic 19 stainless steel specimens. Five roughness measurements were carried out for each 20 material type, providing mean $\mathrm{R}_{\mathrm{a}}$ micro-roughness values of $0.76 \mu \mathrm{m}$ for galvanized 21 steel specimens and $0.03 \mu \mathrm{m}$ for ferritic stainless steel samples. Examples of typical 22 roughness measurements for galvanized and stainless steel specimens are shown in 23 Figure 17. As these figures show, the roughness of the galvanized specimen is about 25 24 times higher than for ferritic stainless steel, which, together with the different material 25 composition, explains the different behaviour in initial slip of the slabs. Nevertheless, 
1 the particular influence of the material type and roughness could not be determined

2 since galvanized steel decks with micro-roughness similar to that shown by the tested

3 stainless steel decks were not available to test.

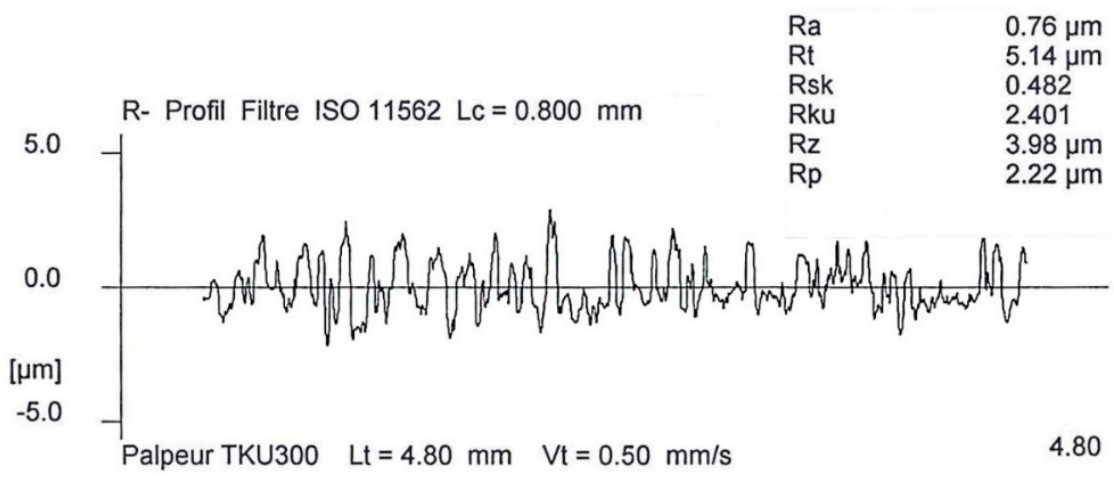

a) In galvanized steel specimen

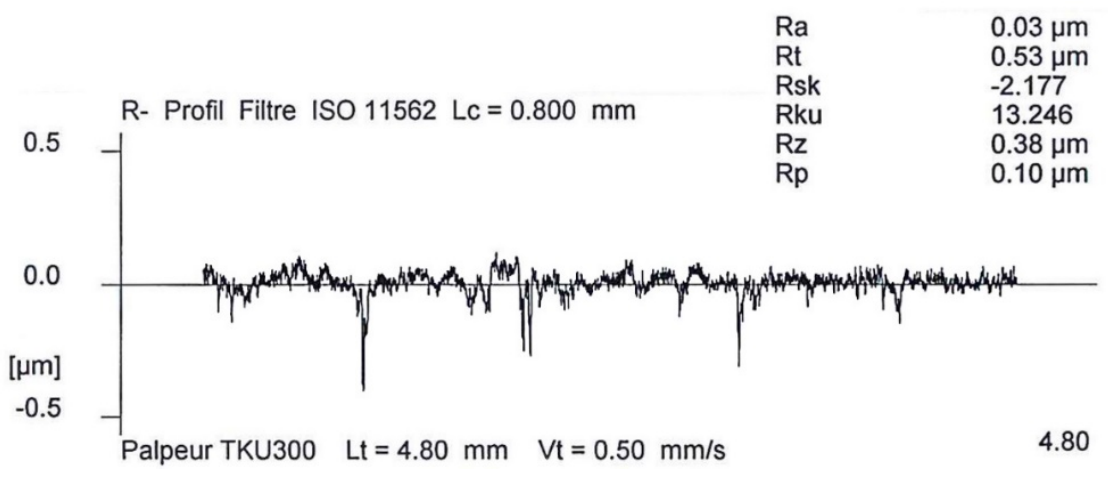

b) In ferritic stainless steel specimen

Figure 17 Roughness measurements

4 However, if stainless steel decks with higher roughness were used for composite slab

5 construction, the need of end anchors or the consideration of the effect of the slip in the

6 calculation of deflections could be avoided according to the conclusions in [36].

7 Hereafter, it is important to ensure that the side of the stainless steel deck which will be

8 in contact with concrete has the appropriate roughness in order to avoid a premature

9 split of the slab. The roughness of the deck surface can be improved by several methods

10 such as bead and shot-blasting by the impact of a hard and inert material (e.g. glass,

11 ceramic, stainless steel shot among others), which provides enhanced surface properties

12 similar to those obtained by acid etching. If a special finish of the deck is needed for 
1 visually exposed construction, this can be solved by providing the required surface

2 finish just to the exposed side of the deck.

\section{5. CONCLUSIONS}

4 This paper presents a comprehensive experimental investigation on eight composite 5 slabs under simply supported conditions with trapezoidal ferritic stainless steel 6 Cofraplus 60 decks, where the behaviour of the specimens in Ultimate and 7 Serviceability Limit States (ULS and SLS) has been studied. The study considered in 8 this paper focused on the longitudinal shear failure mode, characterized by the relative

9 slip between the steel deck and the concrete at supports and which is the most common 10 for composite slabs.

11 The different parameters defining the ultimate longitudinal shear response according 12 to the two design methods provided in EN 1994-1-1: 2004 [1] have been determined 13 from the full scale tests:

14 - The $m$ and $k$ parameters for ferritic stainless steel decks equal to $m=134 \mathrm{~N} / \mathrm{mm}^{2}$ 15 and $k=-0.0329 \mathrm{~N} / \mathrm{mm}^{2}$ were obtained.

16 - Regarding the Partial Connection Method, the longitudinal shear design strengths $17 \tau_{u, R d}$ with and without considering the effect of the support reactions have been 18 determined, which corresponded to $0.092 \mathrm{~N} / \mathrm{mm}^{2}$ and $0.100 \mathrm{~N} / \mathrm{mm}^{2}$ respectively.

19 The behaviour of composite slabs with ferritic stainless steel decks was compared to 20 the performance shown by the reference slabs with galvanized steel deck in terms of 21 ULS and SLS. Experimental results demonstrated that differences on the ultimate loads 22 and parameters governing the ULS are not significant. However, slabs with ferritic 23 stainless steel decks exhibited an early first slip, which was attributed, according to 24 [36], to the different chemical reactions between the concrete and stainless steel and to 25 the considerably lower superficial micro-roughness. 
1 The low resistances corresponding to the $0.5 \mathrm{~mm}$ slips at SLS shown by ferritic

2 stainless steel decks might make necessary end anchors or the consideration of the slip

3 effect in the calculation of deflections under service loads, as established in [1].

4 Nevertheless, this could be avoided if decks showing higher and appropriate roughness

5 at the side in contact with concrete were used for composite slab construction to dodge a

6 premature split of the slab (by means of bead or shot-blasting). For visually exposed

7 slabs, the required surface finish could be provided to the exposed side of the deck.

\section{ACKNOWLEDGMENTS}

9 The research leading to these results has received funding from the European

10 Community's Research Fund for Coal and Steel (RFCS) under Grant Agreement No.

11 RFSR-CT-2010-00026, as well as from the Ministerio de Ciencia e Innovación (Spain)

12 under the Project BIA2010-11876-E “Acciones complementarias”.

\section{REFERENCES}

14

[1] EN 1994-1-1, European Committee for Standardization (2004), "Eurocode 4. Design of composite steel and concrete structures. Part 1-1: General rules and rules for buildings", Brussels, Belgium.

[2] Baddoo, N.R. (2008), "Stainless steel in construction: a review of research, applications, challenges and opportunities", Journal of Constructional Steel Research, 64(11), 1199-1206.

[3] Cashell, K.A. and Baddoo, N.R. (2014), "Ferritic stainless steels in structural applications", Thin-Walled Structures, 83, 169-181.

[4] Baddoo, N.R. (2013), “Steel Appeal”, The Structural Engineer, 91(8), 9-18.

[5] Afshan S. and Gardner L. (2013). "Experimental study of cold-formed ferritic stainless steel hollow sections". Journal of Structural Engineering (ASCE), 139(5), 717-728.

[6] Bock M., Arrayago I. and Real E. (2015). "Experiments on cold-formed ferritic stainless steel slender sections". Journal of Constructional Steel Research, 109, 1323 .

[7] Lecce M. and Rasmussen K.J.R. (2006). "Distortional buckling of cold-formed stainless steel sections: experimental investigation". Journal of Structural Engineering (ASCE), 132(4), 497-504.

[8] Buchanan C., Real E. and Gardner L. (2018). "Testing, simulation and design of cold-formed stainless steel CHS columns". Thin-Walled Structures, 130, Pages 297-312. 
[9] Arrayago I., Real E. and Mirambell E. (2016). "Experimental study on ferritic stainless steel RHS and SHS beam-columns". Thin-Walled Structures, 100, 93104.

[10] Huang Y. and Young B. (2013). "Tests of pin-ended cold-formed lean duplex stainless steel columns". Journal of Constructional Steel Research, 82, 203-215.

[11] Afshan S., Zhao O. and Gardner L. (2017). "Buckling curves for stainless steel tubular columns". Proceedings of Eurosteel 2017, 1 (2-3), 3481-3490.

[12] Di Sarno L., Elnashai A.S., Nethercot D.A. (2005). "Seismic response and design of stainless steel frames". Proceedings of the Fourth International Conference on Advances in Steel Structures 13-15, 1253-1258. Shanghai, China.

[13] Arrayago I., Real E., Mirambell E., Chacón R. "Global plastic design of stainless steel frames". Proceedings of Eurosteel 2017, 1 (2-3), 3463-3471.

[14] Walport F., Nethercot D., Real E., Arrayago I., Gardner L. (2018). Effects of material nonlinearity on the global analysis of stainless steel frames. Journal of Constructional Steel Research. In press

[15] Ferrer, M., Marimon, F., Arrayago, I., Real, E. and Mirambell, E. (2013). "Structural and thermal performance of steel-concrete composite floor systems: Composite slabs test. European Research project: Structural Application of Ferritic Stainless Steels (SAFSS), task 3.3", Technical Report, Funded by the European Community's Research Fund for Coal and Steel (RFCS).

[16] EN 1993-1-3, European Committee for Standardization (2006), "Eurocode 3. Design of steel structures. Part 1-3: General rules. Supplementary rules for coldformed members and sheeting”, Brussels, Belgium.

[17] EN 1993-1-4, European Committee for Standardization (2006) + A1 (2015), "Eurocode 3. Design of steel structures. Part 1-4: General rules. Supplementary rules for stainless steels", Brussels, Belgium.

[18] Arrayago, I., Real, E., Mirambell, E., Marimon, F. and Ferrer, M. (2017), "Experimental study on ferritic stainless steel decks in construction stage", Submitted to Thin-Walled Structures.

[19] ArcelorMittal (2010), “Arval Plancher Collaborant Cofraplus 60”, ArcelorMittal Construction Belgium.

[20] Bonilla, J.D., Bezerra, L.M., Larrúa, R., Recarey, C. and Mirambell, E. (2015), "Study of stud shear connectors behaviour in composite beams with profiled steel sheeting”, Revista de la Construcción 14(3), 47-54.

[21] Chen, S., Shi, X. and Qiu, Z. (2011), "Shear bond failure in composite slabs - a detailed experimental study", Steel and Composite Structures, An Int'l Journal, 11(3).

[22] Cifuentes, H. and Medina, F. (2013), "Experimental study on shear bond behavior of composite slabs according to Eurocode 4", Journal of Constructional Steel Research, 82, 99-110. 
[23] Ferrer, M., Marimon, F. and Crisinel, M. (2006), "Designing cold-formed steel sheets for composite slabs: an experimentally validated FEM approach to slip failure mechanics", Thin-Walled Structures, 44, 1261-1271.

[24] Florides, M.M. and Cashell, K.A. (2017), "Numerical modelling of composite floor slabs subject to large deflections", Structures, 9, 112-122.

[25] Kataoka, M.N., Friedrich, J.T. and El Debs, A.L.H.C. (2017), "Experimental investigation of longitudinal shear behavior for composite floor slab", Steel and Composite Structures, An Int'l Journal, 23(3).

[26] Ranzi, G., Bradford, M.A., Ansourian, P., Filonov, A., Rasmussen, K.J.R., Hogan, T.J. and Uy, B. (2009), "Full-scale tests on composite steel-concrete beams with steel trapezoidal decking", Journal of Constructional Steel Research, 65(7), 14901506.

[27] Saravanan, M., Marimuthu, V., Prabha, P., Arul, Jayachandran S. and Datta, D. (2012), "Experimental investigations on composite slabs to evaluate longitudinal shear strength", Steel and Composite Structures, An Int'l Journal, 13(5).

[28] Bailey, C.G. (2003), "Large scale fire test on a composite slim-floor system". Steel and Composite Structures, An Int'l Journal, 3(3).

[29] Li, G.Q, Zhang, N. and Jiang, J. (2017), "Experimental investigation on thermal and mechanical behaviour of composite floors exposed to standard fire", Fire Safety Journal, 89, 63-76.

[30] Tan, K.H. and Nguyen, T.T. (2015), "Experimental and numerical evaluation of composite floor systems under fire conditions", Journal of Constructional Steel Research, 105, 86-96.

[31] Lauwens, K., Douchya, J., Fortana, M., Arrayago, I., Mirambell, E., Van Gysel, A. and Rossi, B. (2017), "Experimental study of ferritic stainless steel composite slabs", Proceedings of the eighth European Conference on Steel and Composite Structures (EUROSTEEL), 1909-1918.

[32] Luu, T., Bortolotti, E., Parmentier, B., Kestermont, X., Briot, M., Grass, J.-C. (2009), "Experimental investigation of lightweight composite deck slabs", Proceedings of the Ninth International Conference on Steel Concrete Composite and Hybrid Structures (ASCCS), 345-350, Leeds, UK.

[33] EN1990, European Committee for Standardization (2005), "Eurocode 0. Basis of structural design", Brussels, Belgium.

[34] NF-EN1994-1-1/NA, Commission de normalisation de la construction mixte CNCMIX (2007), "Eurocode 4. Calcul des structures mixtes acier-béton. Partie 1-1: Règles générales et règles pour les bâtiments. Annexe Nationale à la NF EN 19941-1:2005”, La Plaine Saint-Denis Cedex, France. 
1 [35] Commission chargée de formuler des Avis Techniques (2014), "Cahier des 2 prescriptions techniques communes aux procédés de planchers collaborants", 3 Marne-la-Vallée Cedex, France.

4 [36] Ertzibengoa, D., Matthys, S. and Taerwe, L. (2012), "Bond behaviour of flat 5 stainless steel rebars in concrete". Materials and Structures, 45, 1639-1653. 6 
